https://doi.org/10.22319/rmcp.v9i3.4247

Artículo

\title{
Detection of rabies virus in organs unrelated to the central nervous system of experimentally-inoculated vampire bats
}

\section{Detección del virus de la rabia en órganos no relacionados con el sistema} nervioso central de murciélagos vampiro experimentalmente infectados

María Luisa Méndez-Ojeda ${ }^{a, b}$

Edith Rojas-Anaya ${ }^{a}$

José Francisco Morales Álvarez ${ }^{a}$

Graciela Tapia-Pérez ${ }^{\mathrm{c}}$

Gerardo Suzán ${ }^{\mathrm{d}}$

Osiris Gaona Pineda ${ }^{\mathrm{e}}$

Rodrigo A Medellín-Legorreta ${ }^{\mathrm{e}}$

Charles E. Rupprecht ${ }^{\mathrm{f}}$

Elizabeth Loza-Rubio ${ }^{\text {a* }}$

a Departamento de Biotecnología en Salud Animal, Centro Nacional de Investigación Disciplinaria en Microbiología Animal, Instituto Nacional de Investigaciones Forestales Agrícolas y Pecuarias, Ciudad de México. México.

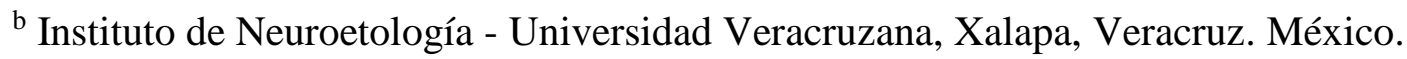

${ }^{\mathrm{c}}$ Departamento de Genética y Bioestadística, Facultad de Medicina Veterinaria y Zootecnia, Universidad Nacional Autónoma de México, Ciudad de México. México.

d Departamento de Etología, Fauna Silvestre y Animales de Laboratorio, Facultad de Medicina Veterinaria y Zootecnia, Universidad Nacional Autónoma de México. Ciudad de México. México.

e Departamento de Ecología y Conservación de Vertebrados, Instituto de Ecología, Universidad Nacional Autónoma de México. Ciudad de México. México. 
${ }^{\mathrm{f}}$ Lyssa LLC. Lawrenceville, Atlanta, Georgia. USA.

* Autor de correspondencia: loza.elizabeth@inifap.gob.mx

\begin{abstract}
- Abstract:
The aim of this research was to detect rabies virus in peripheral tissues in captive vampires. Vampire bats were inoculated with $10^{6} \mathrm{MICLD}_{50}$ of homologous rabies virus. Bats displayed clinical signs of rabies beginning on $\mathrm{d} 8$ until the $19^{\text {th }} \mathrm{d}$ post-inoculation (pi). Rabies virus antigens were found in the brain of all rabid bats. Viral RNA was detected in brain, salivary gland and tongue tissue by RT-PCR and nested PCR (nPCR). Viral genome was also detected in organs unrelated to the central nervous system. Rabies virus was not detected in saliva nor documented from any tissues without occurrence of viral antigens in the brain. Host humoral response was most pronounced via the induction of viral neutralizing antibodies (VNA) from d 8 to 20 pi, having a peak at d 14 with 0.9 IU. Antibody levels were variable, but tended to remain high after inoculation, showing significant differences to the negative control group $(P=0.001)$. This research is one of the few recent studies focused upon Desmodus rotundus and contributes to the basic knowledge of rabies virus pathogenesis, which is required for an understanding of perpetuation in a major viral reservoir in Latin America.
\end{abstract}

- Key words: Desmodus rotundus, Pathogenesis, Rabies, Vampire bat, Zoonosis.

\title{
- Resumen:
}

El objetivo de esta investigación fue detectar el virus de la rabia en tejidos periféricos en vampiros en cautiverio. Los vampiros se inocularon con $10^{6}$ MICLD 50 de un virus de rabia homólogo. Los murciélagos mostraron signos clínicos de la enfermedad desde el día 8 hasta el día 19 postinoculación (pi). Los antígenos del virus de la rabia fueron encontrados en el cerebro de todos los murciélagos infectados. El ARN viral fue detectado en cerebro, glándulas salivales y lengua por RT-PCR y PCR anidado (nPCR). El genoma viral fue también detectado en órganos no relacionados con el sistema nervioso central. El virus de la rabia no se detectó en la saliva ni se documentó en ningún tejido sin la presencia de antígenos virales en el cerebro. La respuesta humoral fue más pronunciada después de la inducción de anticuerpos neutralizantes virales (VNA) desde el día 8 a 20 pi, teniendo un pico en el día 14 con 0.9 UI. Los niveles de anticuerpos fueron variables, con tendencia a permanecer altos después de la inoculación, mostrando diferencias significativas con el grupo control negativo $(P=0.001)$. Esta investigación es uno de los pocos estudios recientes enfocados en Desmodus rotundus que contribuye al conocimiento básico de la patogénesis del virus de la rabia, que 
es necesaria para comprender la perpetuación en un importante reservorio viral en América Latina.

- Palabras clave: Desmodus rotundus, Patogénesis, Rabia, Murciélagos vampiro, Zoonosis.

Recibido 14/08/2016.

Aceptado 04/10/2017.

\section{Introducción}

Within the Americas, rabies is characterized in two major epidemiologic forms, domestic animal rabies and wildlife rabies. In the former, dogs are the main viral reservoir and for the latter, several species of wild carnivores and bats maintain largely independent enzootic rabies virus (RABV) cycles. Domestic animals rabies is managed typically through widespread vaccination of dogs. In contrast, no effective methods have been developed for the long-term effective prevention and control of rabies among bat populations. Although RABV may perpetuate among all major New World bat taxa, one species has special prominence. In the tropical and subtropical areas from Mexico to Northern Argentina, RABV is transmitted to humans, domestic animals, bats and other wildlife by the common vampire bat, Desmodus rotundus ${ }^{(1,2)}$.

Anthropogenic changes have caused deforestation and fragmented landscapes and has exacerbated the vampire bat rabies problem. Such actions may impact vampire bats directly, with the need to seek alternative refugia (e.g., wells, sewers, etc.), and by altering foraging strategies $^{(3)}$. Vampire bats consume the blood of most available mammals, but feed readily on cattle ${ }^{(4)}$, which are a more common prey source than wildlife or humans ${ }^{(2,5)}$.

Throughout Latin America, a broad circulation of homologous RABV among vampire bats has been shown by extensive reported infections in other wildlife, livestock and companion $\operatorname{animals}^{(6,7,8)}$.

Recently, several studies have been published in Europe and North America concerning experimental inoculation of insectivorous bats, using homologous $\operatorname{RABV}^{(9,10,11)}$, Irkut virus $\left(\right.$ IRKV) ${ }^{(12)}$ as well as heterologous viruses (European bat lyssavirus 1 (EBL-1) and European 
bat lyssavirus 1 (EBL-2) ${ }^{(11-16)}$. By comparison, only a few studies have been conducted on hematophagous bats ${ }^{(17-20)}$, in an attempt to understand the transmission and perpetuation of RABV in wild populations of D. rotundus. Therefore, the aim of this study was to detect $\mathrm{RABV}$ in peripheral tissues in experimental infected vampires in captivity by molecular techniques.

\section{Material and methods}

\section{- Vampire bats}

Thirty-three (33) female adult hematophagous bats (D. rotundus) with an average weight of $30 \mathrm{~g}$ were captured in summer using mist nets in Veracruz, Mexico. During the capture, only apparently healthy individuals were taken. Bats were transported in cages to the INIFAP, CENID Microbiology laboratory animal BSL-2 facility and were kept in captivity for $40 \mathrm{~d}$ before use. The animals were housed in two different and separated cages. In the first one inoculated bats were housed and in the second one control animals were housed. The animal room was maintained at an average of $26{ }^{\circ} \mathrm{C}$ and a relative humidity of $60 \%$. Bats were fed daily with $20 \mathrm{ml} /$ each of defibrinated bovine blood. These bats were seronegative for virus neutralizing antibodies (VNA) tested by the rapid fluorescent focus inhibition test (RFFIT) $\left(<0.06 \mathrm{IU} / \mathrm{ml}\right.$, as described Turmelle et $a l^{(10)}$.

\section{- Ethics statement}

All bats were collected in recognition with Mexican regulation NOM-062-ZOO-1999(21), under the sample collection permit Num/SGPA/DGVS: 03173/14 given by the Servicio 
Nacional de Sanidad, Inocuidad y Calidad Agroalimentaria. This study was carried out in strict accordance with the recommendations for the use of animals and was approved by the Institutional Animal Care and Use Committee (IACUC) of the Centro Nacional de Investigación Disciplinaria en Microbiología Animal (Approval \#001-2013). The animals were euthanized by cervical dislocation, according to the guidelines of the Mexican Regulation NOM-033-ZOO-1995(22) for the euthanasia of domestic and wild animals.

\section{- Virus}

A homologous RABV (CASS-88 passage 2) was isolated from a naturally infected vampire bat $^{(23)}$ and replicated in BHK-21 cells. Virus stock, supernatant of homogenized infected mouse brains, for inoculation of vampires in this experiment was prepared as described previously ${ }^{(24)}$. The inoculum before and after administration to the vampires was used for RNA extraction, cDNA and PCR ${ }^{(25)}$ to sequence the RABV N gene (Genbank KP202393).

\section{- Experimental infection}

As mentioned, all individuals used in this study were seronegative during the quarantine period. Subsequently, 22 bats were chosen to be inoculated intramuscularly (IM) in the gluteus muscle with $50 \mu 1$ containing $10^{6}$ MICLD $_{50}$ doses of the homologous RABV CASS$88^{(23)}$. A control group consisted of 11 individuals and were inoculated with a supernatant of homogenized non-infected mouse brains.

\section{- Clinical signs}

Bats were observed at least twice daily to distinguish their behavior and record characteristic signs of RABV infection (e.g., inappetence, lack of grooming, partial or generalized paralysis, coma, etc.). When signs appeared, the sick bat was separated from the group, 
sedated and bled to obtain serum to detect RABV VNA. Thereafter, bats were euthanized according with the NOM-033-ZOO-1995 ${ }^{(22)}$ protocol for experimentation with animals. The euthanized animals were submitted to necropsy for organ extraction. A sampling schedule was established for the routine collection of two inoculated vampires and one control animal post inoculation (pi). The sampling days are listed in Table 1. On the days where an animal of the inoculated group died naturally, it was necessary to sacrifice an animal of the control group to compare the results.

Table 1: Antibodies, fluorescent antibody test (FAT) and molecular assays in organs from inoculated vampires with homologous rabies virus

\begin{tabular}{|c|c|c|c|c|c|c|c|c|c|c|c|c|c|}
\hline \multirow{2}{*}{$\begin{array}{l}\text { Sampling } \\
\text { days }\end{array}$} & \multirow{2}{*}{$\begin{array}{c}\text { Bats } \\
\text { dying/day }\end{array}$} & \multirow{2}{*}{ VNA IU/ml } & \multirow{2}{*}{$\begin{array}{c}\text { FAT } \\
\text { in brain }\end{array}$} & \multicolumn{10}{|c|}{$\mathrm{nPCR}$} \\
\hline & & & & Muscle & Heart & Lung & Liver & Stomach & Spleen & Kidney & S.G & Tongue & Brain \\
\hline 0 & 1 & 0.027 & - & - & - & - & - & - & - & - & - & - & - \\
\hline 4 & 2 & 0.042 & - & - & - & - & - & - & - & - & - & - & - \\
\hline 8 & 2 & 0.065 & - & - & - & - & - & - & - & - & - & - & - \\
\hline $9^{*}$ & 1 & 0.25 & + & - & - & - & - & - & - & - & - & + & + \\
\hline $10^{*}$ & 2 & 0.56 & + & - & - & - & - & - & - & - & - & - & + \\
\hline 11 & 1 & 0.77 & + & - & - & + & + & - & - & + & + & - & + \\
\hline 12 & 2 & 0.73 & + & - & - & - & - & - & - & - & - & + & + \\
\hline $13^{*}$ & 3 & 0.74 & + & - & - & - & - & - & - & - & - & - & + \\
\hline 14 & 2 & 0.92 & + & - & - & + & + & - & - & - & - & - & + \\
\hline $15^{*}$ & 2 & 0.80 & + & - & - & - & - & - & - & + & - & - & + \\
\hline $17^{*}$ & 2 & 0.71 & + & - & - & - & - & - & + & - & - & - & + \\
\hline $19^{*}$ & 1 & 0.66 & + & + & - & + & + & + & + & - & - & - & + \\
\hline 20 & 1 & 0.83 & + & - & - & - & - & - & - & - & - & - & + \\
\hline total & 22 & & 16 & & & & & & & & & & \\
\hline
\end{tabular}

VNA: Mean of virus neutralizing antibodies when two animals were sampled.

$(+)$ Positive test is the result obtained by animals death mentioned on 2 nd column.

(-) Negative test.

S.G= salivary glands.

* mice succumbed with signs rabies related. The days marked in bold represent bats that died from rabies, whereas others were euthanized in the schedule.

The gluteus muscle (site of inoculation), heart, lung, liver, stomach, spleen, kidney, salivary glands, tongue and brain were preserved in 'RNA later' at $-70^{\circ} \mathrm{C}$ until use. In the case of the muscle, salivary gland, heart and brain, the whole organs were used for the extraction, while the remaining organs a macerated was performed to use the supernatant in the RNA 
extraction. Additionally, a portion of the brain was used to conduct the direct fluorescent antibody test (FAT) test for detection of RABV antigens, as described ${ }^{(26)}$.

\section{- Determination of RABV antibodies 。}

Bats were bled to detect virus neutralizing antibodies (VNA) in serum using the RFFIT ${ }^{(27,28)}$. Bat-origin RABV was used as a positive control and rabbit hyperimmune serum with 2 IU/ml. A negative rabbit serum was used as a negative control. The samples were taken before challenge and on the same days that those organs were obtained. The cutoff level used to discriminate positive VNA titers was $\geq 0.06 \mathrm{IU} / \mathrm{ml}^{(10)}$.

\section{- Oral swabs 。}

Oral swabs were obtained during each scheduled time point from each bat and placed into $0.5 \mathrm{ml}$ of MEM for the mouse isolation test (MIT) ${ }^{(24)}$ or in 'RNA later' for the molecular test described, with the samples stored at $-70^{\circ} \mathrm{C}$ until use. The oral swabs were used in the MIT for intra cranial inoculation in suckling mice.

\section{RNA extraction, cDNA Synthesis, RT-PCR and nPCR}

Total RNA was extracted directly from tissues using the trizol reagent ${ }^{\circledR}$ (Invitrogen, Carlsbad, CA, USA), according to the manufacturer's instructions. The RNA pellet was diluted in DEPC-water and quantified with a spectrophotometer (NanoDrop 2000, Thermo- 
Scientific) and stored at $-70{ }^{\circ} \mathrm{C}$. Synthesis of complementary DNA (cDNA) and RT-PCR was performed $^{(25)}$ to detect 761 bp of $\mathrm{N}$ gene. Additionally, in-house nPCR primers were designed using RABV vampire sequences to an amplified 162 bp of same gene in order to enhancer sensitivity and specificity: For: 5'GCCGCRATGCAGTTGTTTGA 3', Rev: 5'ACAGTRGGGTCCCTTGTCA 3'.

\section{- Statistical analysis}

Analysis of detection of RABV in organs was conducted by Log Rank analysis KaplanMeier ${ }^{(29)}$. Levels of VNA in serum were analyzed using a logarithmic sequence estimation (regression curve fit of SPSS). The analysis were conducted using the statistical package SPSS 2.0.

\section{Results}

\section{- Serology •}

After inoculation, the VNA titers were detected from d 9 to 20, in which all bats had either succumbed or were euthanized (Table 1). The VNA peak appeared at d 14 with $0.9 \mathrm{IU} / \mathrm{ml}$. Non-inoculated bats showed values less than the cut-off considered negative, while levels in inoculated ones showed a rising trend. The predicted logarithmic model (ln) observed values for $60 \%$ of the data $(P=0.001)$. 


\section{- Survival •}

Some bats succumbed naturally to infection at $\mathrm{d} 9,10,11,13,15,17$ and 19 . Animals showed a short period of depression, hyperactivity and anorexia, but no aggressive behavior. The remaining bats were euthanized at $\mathrm{d} 0,4,8,12,14,16$ and 20 according to the schedule (Table 1). The $95 \%$ confidence interval for the survival of inoculated vampires was 12.5 , $16.4 \%$ with a mean of $14.4 \%$. All uninoculated control vampires survived, as expected. The mortality per day in vampires after inoculation with RABV was different $(P=0.02)$, compared

to all animals not inoculated. The non-infected animals were negative by both assays for every sample.

\section{- Detection of RABV antigens}

Of the 22 bats inoculated with RABV signs of rabies were identified in 16, (72\%). These 16 animals were confirmed by FAT. The mean incubation period was $13 \mathrm{~d}$, with a range of 9 to $19 \mathrm{~d}$ pi. Clinical signs included: inappetence, lack of grooming, partial or generalized paralysis, coma and acute death, but no aggressive behavior. Presence of RABV was detected in brains of vampires from d 9 (Table 1). No RABV was detected in the control group. Moreover, all oral swabs were negative via the MIT.

\section{- RT-PCR and nPCR 。}

Brains were positive from d 9 pi until d 19, compatible with the same results as observed with FAT. Additionally, the RT-PCR was capable of detecting RABV in tongue on $\mathrm{d} 9$ and 12 of all evaluated animals. In other individuals, no other positive organ was found by RTPCR. However, when analyzed by nPCR, some other organs, such as salivary glands, lung, 
liver, kidney and spleen, were positive between d 11 and 19, demonstrating the presence RABV in organs unrelated to the CNS. A Log Rank analysis (Kaplan-Meier) showed highly significant differences in the dispersion of the appearance of RABV among organs $(P=$ 0.001), showing a higher probability of being expressed in the brain. (Table 1). No RABV nucleic acids were detected in any saliva samples. Analysis of probability of occurrence of RABV in organs for each day showed highly significant differences in the spread of virus to first appearance among the other organs $(P=0.001)$. In analyzing the brain, it had the highest probability of occurrence, while muscle tissue was least likely.

\section{\| Discussion V}

Data obtained from experimental studies of etiological agents in relevant susceptible hosts should provide insights for understanding pathogen transmission and perpetuation among reservoirs in nature. As such, several investigations on vampires have been conducted to study RABV pathobiology in these unique hematophagous species ${ }^{(17-20)}$. Throughout such studies, comparative levels of the presence of VNA were determined. Despite the recognition that induction of VNA is a critical effector mechanism and the established international standard of $0.5 \mathrm{IU} / \mathrm{ml}$ selected as evidence of an adequate immunological response following vaccination, apparently there are no proven levels of "protection" against a RABV infection, considering the vagaries of virus, dose, route, severity and species dynamics. In this study, once infection was initiated, RABV antibodies were detected from d 8 at 0.07 IU up to $\mathrm{d} 20$ at $0.8 \mathrm{IU} / \mathrm{ml}$, with a peak at $\mathrm{d} 14$ with $0.9 \mathrm{IU}$. obviously, the degree of resistance indicated by the presence of VNA does not necessarily always correlate with protective immunity. This has been observed under both free-living and experimental conditions ${ }^{(19,30,31)}$.

In this work as in others, a modification of the RFFIT was used to determine the VNA in the animals before the experiment. To verify that the animals to be used were seronegative at the time of initiation of the experiment, they were kept in quarantine and were determined to maintain a titer $<0.06 \mathrm{IU} / \mathrm{ml}$, considered negative; even though the animals come from an area that is reported in the literature as endemic for the virus.

Specifically, in this study, the presence of VNA was not correlated with survivorship due to RABV infection because even animals showing antibody titers above $0.9 \mathrm{IU} / \mathrm{ml}$ succumbed to the infection. The above was probably due to the time when virus has reached the CNS and thus VNA in the periphery were unable to clear the virus. The statistical analysis 
predicted that the VNA would increase gradually with the increasing day of infection. However, in some individuals the presence of VNA was unable to skew the progression towards survivorship, as at d 13 in which three individuals succumbed, marking a peak of clinical manifestation.

Using an insectivorous species, Jackson et $a l^{(9)}$ determined titers that ranged from 0.3 to 8 $\mathrm{IU} / \mathrm{ml}$ in Eptesicus fuscus, inoculated IM with a RABV at $10^{3.2} \mathrm{MICLD} 50$ dose. In another study, rabies VNA titers in big brown bats fluctuated through time, indicating repeated RABV exposure and that antibodies are not related with virus clearance ${ }^{(10,32)}$. According to Turmelle et $a l^{(10)}$, antibody presence may be transitory. Our sampling protocol was determined with the purpose of determining the presence of RABV within organs before death occurred. In this research, signs began at d 9 through d 19 pi, while in other studies deaths occurred earlier using the same dosage, although our sampling schedule was located inside the range of other studies, with variation possibly due to differential individual response of bats to these pathogens ${ }^{(18,33)}$.

Vampire susceptibility in prior studies reached 79 and $84 \%$ at a dose of $10^{6}$ MICLD $_{50}$, and other authors have reported a susceptibility on average of $60 \%$ using lower dosages ${ }^{(18,19,33)}$. Although one study carried out experimental inoculation in a different host (E. fuscus), $75 \%$ of the inoculated bats presented clinical signs at d 12 with an incubation period between 13 and $17 \mathrm{~d}^{(9)}$.

Using conventional molecular tools to identify RABV targets, this study detected nucleic acids in the brain and tongue. However, the nPCR designed using Mexican bat RABV sequences was more sensitive than RT-PCR alone, since various temporal stages were detected in organs unrelated to the brain, including lung, liver, kidney, spleen and even muscle and stomach (at d 19 pi). These results agree with those obtained elsewhere ${ }^{(7)}$, who detected RABV genome in various tissues, including reproductive organs, when using real time PCR. Considering potential portals of exit, it was found RABV in the salivary glands at d 11 pi, although some results ${ }^{(19)}$ reported that RABV fragments could only be detected in some individuals. Moreno and $\mathrm{Baer}^{(20)}$, when inoculating vampire bats via intracranial injection, found RABV at high percentages in parotid, submaxillary and sublingual glands. By contrast, when injecting IM, RABV was detected in only $57 \%$ of the salivary glands. These studies provide evidence of the high variability of detection of RABV after primary replication in the brain ${ }^{(19)}$. The time schedule may have been inadequate to detect RABV in a more dynamic manner. To allow a better understanding of the perpetuation of infection in this species, considering their highly gregarious lifestyle, a daily sampling protocol should be considered in different fluids, tissues and organs using several routes of administration and doses.

Specific viral detection in rabid bats varies by species and the particular methods used in regards to dose and route. For example, some researchers ${ }^{(11)}$ detected a fragment of RABV 
in insectivorous bats only in salivary glands and nervous tissue, but they also reported differing results using PCR and isolation with these same tissues. In the present study, it was not possible to detect RABV in saliva either by molecular tools or biological tests, which could be related to the inoculation pathway used. Some reports ${ }^{(18)}$, detected RABV in saliva in surviving individuals at 6 and $21 \mathrm{~d}$ by cell culture, while in this study MIT was used, which is a historical test for isolation and at least as sensitive as cell culture. Davis $e t a l^{(11)}$ were unable to detect RABV in saliva of the insectivorous bat Myotis lucifugus subcutaneously inoculated. Other work ${ }^{(9)}$, detected RABV in only $10 \%$ of E. fuscus, which had been inoculated IM with a homologous RABV, although positive samples were detected before the onset of disease and none of the survivors showed viral excretion.

Likely, the immune system of bats plays an important role in limitation of viral tropism and could be capable of allowing individuals to elude a productive viral infection, in contrast to many other mammalian taxa, in which apparent herd immunity is limited. One hypothesis suggests that the innate immune system rapidly controls viral replication to very low levels, limiting clinical consequences in bats, but still resulting in viral shedding and subsequent spillover to other species ${ }^{(34,35)}$. To date, these have not been described in hematophagous bats, but this could be a possible explanation for not detecting genome or virus in saliva samples.

\section{Conclusions and implications}

Primary RT-PCR was incapable of detecting RABV N gene in tested organs, except in the brain. Using a novel nPCR implemented in-house using Mexican vampire sequences, RABV was detected in organs unrelated to the central nervous system of vampire bats experimentally inoculated. Overall, this study contributes to the knowledge on the pathogenesis of RABV in one of the major primary reservoirs in Latin America.

\section{Acknowledgments}

This study was partially financed by grant 80275 (CONACyT-Mexico). 


\section{- Literature cited}

1. Loza-Rubio E, Nadin-Davis SA, Morales SE. Molecular and biological properties of rabies viruses circulating in Mexican skunks: focus on P gene variation. Rev Mex Cienc Pecu 2012;3:155-170.

2. Delpietro HA, Marchevsky N, Simonetti E. Relative population densities and predation of the common vampire bat (Desmodus rotundus) in natural and cattle-raising areas in north-east Argentina. Prev Vet Med 1992;14:13-20.

3. Rico-Chávez O, Ojeda FR, Sotomayor BJ, Zambrana-Torrelio C, Loza-Rubio E, Alonso AA, Suzán G. Diversidad viral de comunidades de murciélagos en paisajes transformados de México. Vet Méx 2015;2:1-23.

4. Belotto A, Leanes LF, Schneider MC, Tamayo H, Correa E. Overview of rabies in the Americas. Virus Res 2005;111:5-12.

5. Johnson N, Aréchiga-Ceballos N, Aguilar-Setién A. Vampire bat rabies: Ecology, epidemiology and control. Viruses 2014;6:1911-1928.

6. Favoretto SR, Carrieri ML, Cunha EM, Aguiar EA, Silva LH, Sodre MM, Souza MC, Kotait I. Antigenic typing of Brazilian rabies virus samples isolated from animals and humans, 1989-2000. Rev Inst Med Trop Sao Paulo 2002;44:91-95.

7. Carneiro AJ, Franke CR, Stocker A, Dos Santos F, Ungar de Sa JE, Morales-Silva E, et al. Rabies virus RNA in naturally infected vampire bats, northeastern Brazil. Emerg Infect Dis J 2010;16:2004-2006.

8. Schneider MC, Romijn PC, Uieda W, Tamayo H, Da Silva DF, Belotto A, Da Silva JB, Leanes LF. Rabies transmitted by vampire bats to humans: an emerging zoonotic disease in Latin America?. Rev Pan Salud Pública 2009;25:260-269.

9. Jackson FR, Turmelle AS, Farino DM, Franka R, McCracken GF, Rupprecht CE. Experimental rabies virus infection of big brown bats (Eptesicus fuscus). J Wild Life Dis 2008;44:612-621.

10. Turmelle AS, Jackson FR, Green D, McCracken GF, Rupprecht CE. Host immunity to repeated rabies virus infection in big brown bats. J Gen Virol 2010;91:2360-2366. 
11. Davis AD, Jarvis JA, Pouliott CE, Morgan MD, Rudd RJ. Susceptibility and pathogenesis of little brown bats (Myotis lucifugus) to heterologous and homologous rabies viruses. J Virol 2013;87:9008-9015.

12. Kuzmin IV, Franka R, Rupprecht CE. Experimental infection of big brown bats (Eptesicus fuscus) with West Caucasian bat virus (WCBV). Develop Biolog (Basel) 2008;131:327-37.

13. Davis AD, Jarvis JA, Pouliott C, Rudd RJ. Rabies virus infection in Eptesicus fuscus bats born in captivity (naïve bats). PLOS One 2013b;8:e64808.

14. Freuling C, Vos A, Johnson N, Kaipf I, Denzinger A, Neubert L, Mansfield K, Hicks D, Nuñez A, Tordo N, Rupprecht CE, Fooks AR, Müller T. Experimental infection of serotine bats (Eptesicus serotinus) with European bat lyssavirus type 1a. J Gen Virol 2009;90:2493-502.

15. Fooks AR, Johnson N, Müller T, Vos A, Mansfield K, Hicks D, et al. Detection of high levels of European bat lyssavirus type-1 viral RNA in the thyroid gland of experimentally-infected Eptesicus fuscus bats. Zoo Pub Health 2009;56:270-277.

16. Franka R, Johnson N, Müller T, Vos A, Neubert L, Freuling C, Rupprecht CE, Fooks AR. Susceptibility of North American big brown bats (Eptesicus fuscus) to infection with European bat lyssavirus type 1. J Gen Virol 2008;89:1998-2010.

17. Aparecida MC, Souza M, Figueiredo A, Nassar A, Cortez A, et al. Experimental of vampire bats Desmodus rotundus (E. Geoffroy) maintained in captivity by feeding defibrinated blood added with rabies virus. Brazilian J Vet Res Anim Sci 2009;46:92100.

18. Aguilar-Setién A, Loza-Rubio E, Salas-Rojas M, Brisseau N, Cliquet F, Pastoret PP, et al. Salivary excretion of rabies virus in healthy vampire bats. Epidemiol Infect 2005; 133:517-522.

19. Almeida MF, Martorelli LFA, Aires CC, Sallum PC, Durigon EL, Massad E. Experimental rabies infection in haematophagous bats Desmodus rotundus. Epidemiol Infect 2005; 133:523-527.

20. Moreno JA, Baer GM. Experimental rabies in the vampire bat. The American J Trop Med Hyg 1980;29:254-259.

21. Norma Oficial Mexicana NOM-062-ZOO-1999. 1999. Especificaciones Técnicas para la producción, cuidado y uso de los animales de laboratorio, www.senasica.gob.mx/?doc=743. Consultado 15 Nov, 2015. 
22. Norma Oficial Mexicana NOM-033-ZOO-1995. 1996. Sacrificio humanitario de los animales domésticos y silvestres, www.senasica.gob.mx/?doc=529. Consultado 15 Nov. 2015.

23. Cuevas-Romero S, Colmenares VG, Batalla CD, Hernández BE. Selección de un virus rábico de origen vampiro para utilizarse como cepa de desafío en bovino. Vet Méx 1989;20:271-275.

24. Koprowski H. The mouse inoculation test. In: Meslin FX, et al. editors. Laboratory techniques in rabies. $4^{\text {th }}$ ed. Geneva, Switzerland: WHO; 1996:80-87.

25. Loza-Rubio E, Rojas-Anaya E, Banda-Ruiz VM, Nadin-Davis SA, Cortez-Garcia B. Detection of multiple strains of rabies virus RNA using primers designed to target Mexican vampire bat variants. Epidemiol Infect 2005;133:927-934.

26. Dean DJ, Abelseth MK, Atanasiu W. The fluorescent antibody technique in rabies. In: Meslin FX, et al. editors. Laboratory techniques in rabies. $4^{\text {th }}$ ed. Geneva, Switzerland: WHO; 1996:88-95.

27. Smith JS, Yager PA, Baer GM. A rapid fluorescent focus inhibition test (RFFIT) for determining rabies virus-neutralizing antibody. In: Meslin FX, et al. editors. Laboratory techniques in rabies. $4^{\text {th }}$ ed. Geneva, Switzerland: WHO; 1996:181-191.

28. Johnson N, Vos A, Neubert L, Freuling C, Mansfield KL, Kaipf I, et al. Experimental study of European bat lyssavirus type-2 infection in Daubenton's bats (Myotis daubentonii). J Gen Virol 2008;89:2662-2672.

29. Aguayo CM, Lora ME. Como hacer "paso a paso" un Análisis de supervivencia con SPSS para Windows. Fabis 2007;0702006:1-11.

30. Gilbert AT, Fooks AR, Hayman DT, Horton DL, Müller T, Plowright R, et al. Deciphering serology to understand the ecology of infectious diseases in wildlife. EcoHealth 2013;10:298-313.

31. Mani RS, Dovih DP, Ashwini Ma, Chattopadhyay B, Harsha PK, Garg KM, et al. Serological evidence of Lyssavirus infection among bats in Nagaland, a North-Eastern State in India. Epidemiol Infect 2017;145:1635-1641.

32. O’Shea TJ, Shankar V, Bowen RA, Rupprecht CE, Wimsatt JH. Do bats acquire immunity to rabies? Evidence from the field. Bat Research News. 2003;44:161.

33. Aguilar-Sétien A, Brochier B, Tordo N, De Paz O, Desmettre P, Péharpré D, Pastoret PP. Experimental rabies infection and oral vaccination in vampire bats (Desmodous rotundus). Vaccine 1998;16:1122-1126. 
34. Cowled C, Stewart CR, Likic VA, Friedländer MR, Tachedjian M, Jenkins KA, et al. Characterization of novel microRNAs in the Black flying fox (Pteropus alecto) by deep sequencing. BMC Genomics 2014;15:682.

35. He X, Korytař T, Schatz J, Freuling CM, Müller T, Köllner B. Anti-lyssaviral activity of interferons $\kappa$ and $\omega$ from the serotine bat, Eptesicus serotinus. J Virol 2014;88:54445454. 